\title{
A Case of Amniotic Band Syndrome with Cleft Lip and Palate
}

\author{
Yutaka Doi · Hitoshi Kawamata $\cdot$ Kazuhiro Asano • \\ Yutaka Imai
}

Received: 29 June 2009/ Accepted: 24 January 2011/Published online: 25 February 2011

(C) Association of Oral and Maxillofacial Surgeons of India 2011

\begin{abstract}
The patient was a 5-day-old boy born at 37 weeks and 4 days. At birth, an amniotic band encircling and constricting his left middle finger was noted, in addition to multiple anomalies including a right-side cleft lip and palate, a club foot, and syndactyly on the left hand. We performed cheiloplasty at 5 months, and palatoplasty at 18 months.
\end{abstract}

Keywords Amniotic band syndrome $\cdot$ Cleft lip and palate $\cdot$ Hotz plate $\cdot$ Club foot $\cdot$ Syndactyly

\section{Introduction}

Amniotic band syndrome is a rare congenital condition in which it is hypothesized that a fibrous band of amniotic tissue results in variable soft tissue derangement. This syndrome is a sporadic condition and is reported to occur in approximately 1 in 1,200-15,000 births [1-5]. The patient may present with craniofacial, thoracic, abdominal, and/or limb involvement. Here we report a case of amniotic band syndrome with cleft lip and palate.

\section{Case Report}

The patient was a 5-day-old boy who was born at 37 weeks and 4 days uneventfully (body weight: $2,375 \mathrm{~g}$ ) on

Y. Doi · H. Kawamata $(\varangle) \cdot$ K. Asano · Y. Imai

Department of Oral and Maxillofacial Surgery,

School of Medicine, Dokkyo Medical University,

880 Kitakobayashi, Mibu, Shimo-tsuga,

Tochigi 321-0293, Japan

e-mail: h-kawama@dokkyomed.ac.jp
September 8, 2005. The Apgar scores were 9 at $1 \mathrm{~min}$ and 10 at $5 \mathrm{~min}$. At birth, an amniotic band encircling and constricting his left middle finger was noted, in addition to multiple anomalies including a right-side cleft lip and palate (Fig. 1), syndactyly on the left hand (Figs. 2, 3), and a club foot (Fig. 4). His mother is 43 years old and his father 38 . No hereditary anomalies, including cleft lip and palate, were observed in his family. His mother did not stop smoking or drinking alcoholic beverages during the pregnancy. The patient used a Hotz plate to assist with milk feeding as well as to improve development of the maxilla. In the newborn period, he was neurologically intact with an appropriate response to stimulation and sleep-and-waking cycle. At four months he manifested age appropriate development and ultrasounds of his heart and abdomen were normal. There were no abnormalities in his blood examination results, ECG, cardiac echogram, abdominal echogram or chromosomal examination. We subsequently performed cheiloplasty by the Cronin's triangular flap method on his right upper lip at five months and palatoplasty by a modified push back method (palatal mucosal flap and muco-periosteal flap for closing of the cleft) at 18 months. Furthermore, orthopedists removed the constriction ring on his left-hand at 10 months.

\section{Discussion}

Forty-nine cases (27 males and 22 females) of oro-facial anomalies associated with amniotic band syndrome were reported in the literature over the past 20 years [1-15]. These cases included 37 cases of facial cleft and 9 cases of cleft lip and palate. Although the precise mechanism for development of oro-facial anomalies associated with amniotic band syndrome is not fully understood, two main theories of the pathogenesis of amniotic band syndrome, 


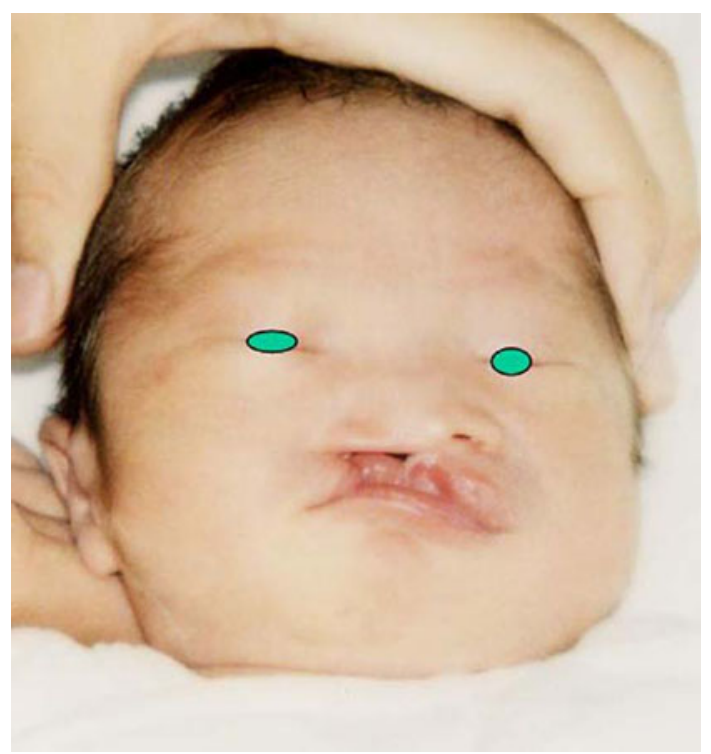

Fig. 1 Front view of the face showing the right-side cleft lip

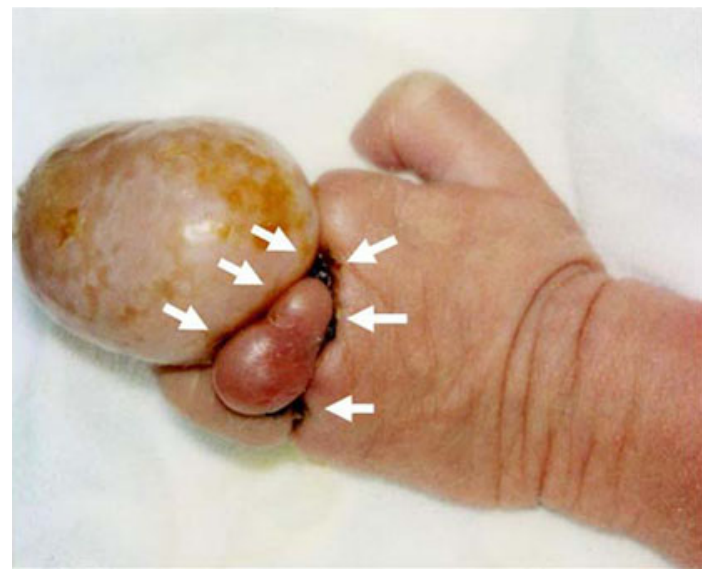

Fig. 2 An amniotic band had encircled and constricted his left middle finger

namely the extrinsic model [16] and intrinsic model [17] can be employed for explaining the development of the oro-facial anomalies associated with this syndrome. The intrinsic model suggests that the anomalies and fibrous bands have a common origin, caused by perturbation of the developing germinal disc in the early embryo. The bands represent either sheets of macerated epidermis or are the result of a circumscribed area of imperfect histogenesis leading to sloughing off necrotic tissue. The aberrant tissue bands represent merely residues of an abnormal development process and not the cause. On the other hand, the extrinsic model suggests that the birth defect is caused by the action of fibrous amniotic bands. At present, the extrinsic model is widely accepted, with the sequence of events involving rupture of the amnion, followed by loss of

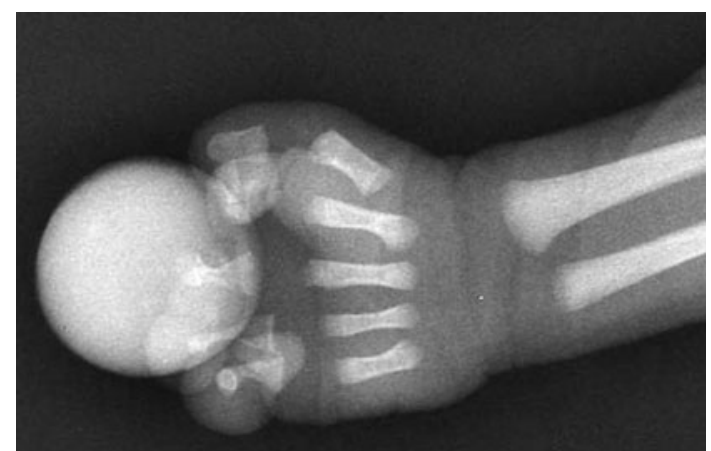

Fig. 3 X-ray of the syndactyly on the left hand

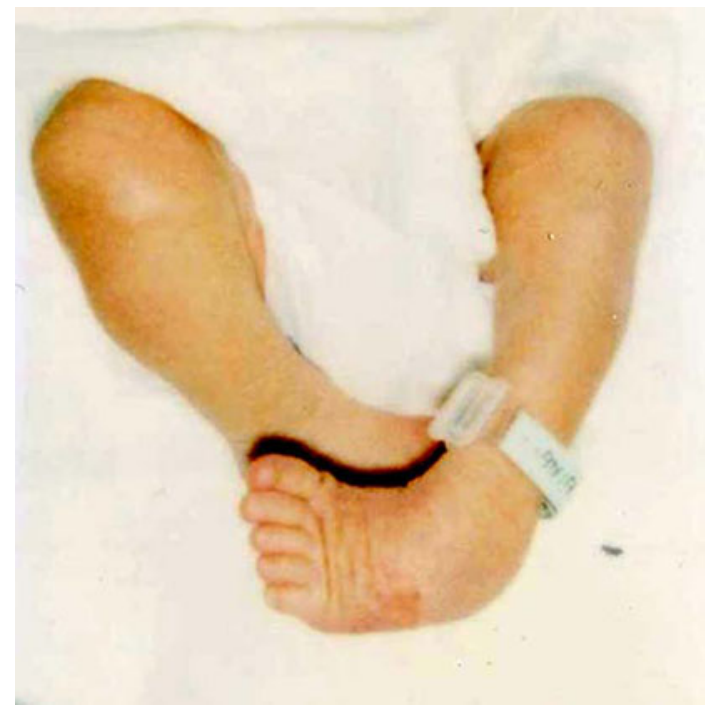

Fig. 4 Club foot

amniotic fluid and extrusion of all or parts of the fetus into the chorionic cavity. While trapped there, the fetus is subjected to compression due to the limited space, and the fetus' limbs and other body parts become entangled in the shriveled, rolled remnants of amnion. The exact nature of the anomalies can be accounted for by the timing of the rupture [18]. However, the extrinsic model cannot adequately explain the involvement of cleft palate and other anomalies of internal organs in amniotic band syndrome. Further investigation including genetic or genomic analysis may be necessary to understand the pathogenesis of amniotic band syndrome.

\section{References}

1. Taub PJ, Bradley JP, Setoguchi Y, Schimmenti L, Kawamoto HK Jr (2003) Typical facial clefting and constriction band anomalies: an unusual association in three unrelated patients. Am J Med Genet A 120:256-260 
2. Pramod K (1996) Cleft lip and amniotic bands. Br J Plast Surg 49:74-75

3. Murasakas JK, Mcdannell JF, Chudik RJ, Salyer KE, Maywood LG (2003) Amniotic band syndrome with significant orofacial clefts and disruptions and distortions of craniofacial structures. J Pediatr Surg 38:635-638

4. Morovic CG, Berwart F, Varas J (2004) Claniofacial anomalies of the amniotic band syndrome in serial clinical cases. Plast Reconstr Surg 113:1556-1562

5. Coady MS, Moore MH, Wallis K (1998) Amniotic band syndrome: the association between rare facial clefts and limb ring constrictions. Plast Reconstr Surg 101:640-649

6. Ray M, Hendrick SJ, Raimer SS, Blackwell SJ (1988) Amniotic band syndrome. Int J Dermatol 27:312-314

7. McCarthy S, Sarwar M, Virapongse C, Ehrenkranz R (1984) Craniofacial anomalies in the amniotic band disruption complex. Pediatr Radiol 14:44-46

8. Kumar P, Tiwari VK (1990) An unusual cleft lip secondary to amniotic bands. Br J Plast Surg 43:492-493

9. Ito M, Onityuka Y, Matsui K, Fujisaki S, Maeyama M (1986) Craniofacial defects associated with amniotic band syndrome: a case report. Int J Gynaecol Obstet 24:43-45

10. Reddy VV, Kulkarni ML, Mehta DS (1991) Amniotic band syndrome (ABS): report of a case. Ann Dent 50:30-32
11. Eppley BL, David L, Min Li, Cynthia AM, Michael SA (1998) Amniotic band facies. J Craniofac Surg 9:360-365

12. Mishima K, Sugahara T, Mori Y, Sakuda M (1996) Three cases of oblique facial cleft. J Craniomaxillofac Surg 24:372-377

13. Jabor MA, Cronin ED (2000) Bilateral cleft lip and plate and limb deformities: a presentation of amniotic band sequence? J Craniofac Surg 11:388-393

14. Nathaniel HR, Judith F, Sandra P, Ashley BR, Johon HG (2005) Cleftin amniotic bands, and polydactyly: a distant phenotype that supports an intrinsic mechanism for amniotic band sequence. Am J Med Genet 137A:298-301

15. Miyajima K, Natsume N, Kawai T, Iizuka T (1994) Oblique facial cleft, cleft palate, and supernumerary teeth secondary to amniotic bands. Cleft Palate Craniofac J 31:483-486

16. Torpin R (1965) Amniotic mesoblastic fibrous strings and amniotic bands. Am J Obstet Gynaecol 91:65-75

17. Streeter GL (1930) Focal deficiencies in fetal tissues and their relation to intra-uterine amputations. Contrib Embryol Carnegie Inst 22:1-46

18. Higginbottom MC, Hones KL, Hall BD, Smith DW (1979) The amniotic band disruption complex: timing of amniotic rupture and variable spectra of consequent defects. J Pediatr 95:544-549 